\title{
The Development of Monitoring Devices in the "Man-Clothes" System Based on Modern Microcontrollers
}

\author{
Alexander Molnar, Vitaly Gerasimov \\ Mukachevo State University, Faculty of Economics, Management and Engineering, 26 Użhgorodska St., 88000 Mukachevo, Ukraine
}

Igor Piotr Kurytnik

State Higher School in Oswiecim, 8 Kolbego St., 32-600 Oświęcim, Poland

\begin{abstract}
In this paper the design of an experimental sample of a portable electronic device for assessment of the basic parameters of the „Man-Clothes” System based on modern wireless microcontroller technology has been discussed and suggested. The mobile measuring system based on TI MSP430 microcontrollers to track the parameters of "smart clothes" has been presented.
\end{abstract}

Keywords: smart clothes, controller, wireless

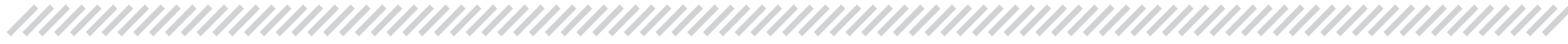

\section{Introduction}

Digital technique and technology intensively enters all the spheres of human activity, and it is difficult to do without modern technologies even in ordinary (home) life. Ten years ago it was hard to imagine the effect of using the ordinary mobile phone. Today, this device can already be attributed to the multifunctional mini computing system. Therefore, it is rightly called a „smartphone”. Regarding the latter, this idea has already been successfully used in the field of a "smart house". This allows to improve the quality and comfort of human living space much more, and moreover, to save the consumption of energy here, which will lead to preservation of the ecological situation. A further aspect of human activity are clothes. Here, the new digital technologies are introduced not so actively. This is due to several reasons. And one of the component parts of such a situation is the relatively weak presence of efficient, and at the same time energy low-consumption microcontrollers on the market. Recently, however, a new generation of microcontrollers has been presented by some leading companies that could easily pretend to be used as the base ones for devices in the field of "smart clothes". The authors have reviewed the microcontrollers of Texas Instruments Company, which, due to their circuitry and parameters, are suitable in this field of application.

\section{Autor korespondujący:}

Igor Piotr Kurytnik, igor.kurytnik@pwsz-oswiecim.edu.pl

\section{Artykuł recenzowany}

nadesłany 7.03.2016 r., przyjęty do druku 10.05.2016 r.

\section{Results and Discussion}

The typical measurement system (Fig. 1) designed for storing, processing, control and visualization of "smart clothes" parameters consists of the following components:

- Primary sensors of physical quantities (temperature, humidity, pressure, strain, etc.);

- Analog devices for amplification, filtering and scaling of signals from the sensors;

- Analog-to-digital and digital-to-analog converters;

- Controlling microprocessors or microcontrollers (MC);

- Interface for connection to the control computer (USB, Bluetooth, Wi-Fi);

- Power supply system for analog and digital circuits [1];

- Devices of information and visualization.

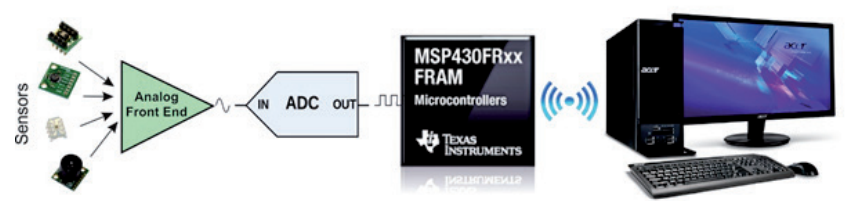

Fig. 1. Typical measurement system

Rys. 1. Typowy system pomiarowy

For wearable electronics systems the increased requirements as to energy efficiency, ability to work from a single-polarity supply, a wide operating temperature range (especially for the rescue services and military uniforms) as well as a high ratio of the operational speed/power consumption are imposed on all the listed elements. These requirements were met a relatively long time ago for sensors and analog input devices, however, the digital components have only recently reached the required level of development. 
The microcontrollers of Texas Instruments MSP430 series [2] should be considered one of the most energy-efficient solutions in the field of embedded microcontrollers. They are specially designed for applications with the ultra low-power consumptiom. They have a flexible clocking system, some lowpower modes, the ability to switch instantly to the active mode and have the intelligent autonomous peripherals, allowing achieving the ultra-low consumption and increasing the battery life greatly. The capacity of the lithium battery is sufficient to power the unit for 5 years.

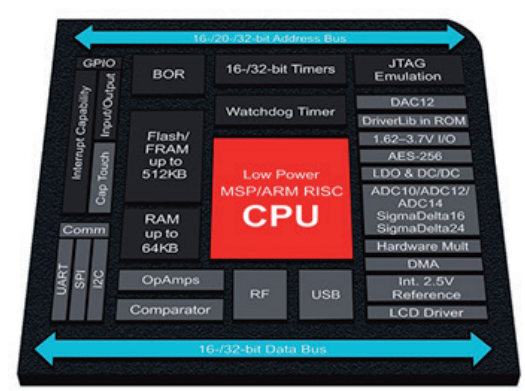

Fig. 2. Internal structure of Texas Instruments' microcontrollers Rys. 2. Struktura wewnętrzna mikrkontrolerów firmy Texas Instruments

Key features of this controller family are (Fig. 2):

- The architecture of the ultra-low power (ULP) and the flexible clock system extend the operating time: data storage in RAM at a current consumption of $0.1 \mu \mathrm{A}$; consumption in RTC mode is less than $1 \mu \mathrm{A}$; less than $230 \mu \mathrm{A} / \mathrm{MIPS}$ (flash) and less than $110 \mu \mathrm{A} / \mathrm{MIPS}$ (RAM);

- Intelligent peripherals, consisting of a wide range of high-performance analog and digital modules that do not use CPU resources: 10- to 14-bit ADC (with conversion frequency up to $1 \mathrm{MHz}$ ), low speed 24-bit delta-sigma ADC, comparator, 12-bit DAC, DMA, multiplier, operational amplifier, timer, watchdog timer, RTC, RF adapters, AES encryption (up to 256 bits), USB, SPI, I² C, LIN/IrDA, LCD controller, etc;

- Easy to use 16-bit processor with RISC architecture and the maximum code density in the industry. The most important features of RISC (Reduced Instruction Set Computer) are: register-register architecture, simple addressing modes,

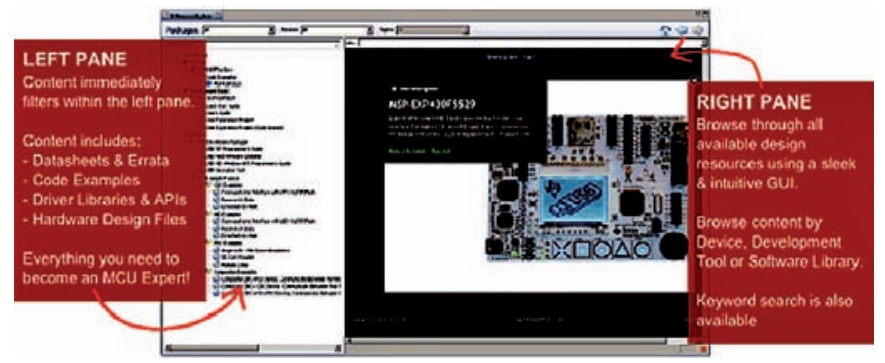

Fig. 3. MSPWare - Advanced development system combines the choice of both hardware and software platform for the future development [3]

Rys. 3. MSPWare - Zaawansowany system łączący dobór platformy sprzętowej i programowej dla przyszłego zastosowania [3]

simple commands and a large register file. MSP430 microcontroller has 27 basic and 24 additional instructions that greatly simplifies the process of generating the programs. There are no special commands of addressing to the battery mode, memory or peripherals. This greatly improves the efficiency of the processor performance.

In addition, the MSP430 series Texas Instruments microcontrollers includes the products labeled "FR" in the title that indicates the use of ferroelectric random access memory (FRAM) instead of the normal flash memory. This type of memory device has several advantages:

- Non-volatile (like a flash memory), when power is being switched off the data are stored;

- High performance at RAM level. This allows to perform a "cold start" or an instant restart of the system with the "preset" parameters;

- The number of read-write cycles is almost infinite (in fact, of the order of $10^{15}$ write cycles). A prior erasure of the recorded data is not needed;

- Energy efficiency is 3 times better than in case of the flash technology.

Table 1 shows the comparative characteristics of FRAM, compared with the other types of memory.

And all the "intelligent" peripherals directly (without CPU involvement) write to the FRAM memory. What does this mean in practice? For example, the ADC results are written directly to the FRAM memory which allows to save the data,

Table 1. The comparative characteristics of FRAM

Tabela 1. Charakterystyka porównawcza pamięci o swobodnym dostępie

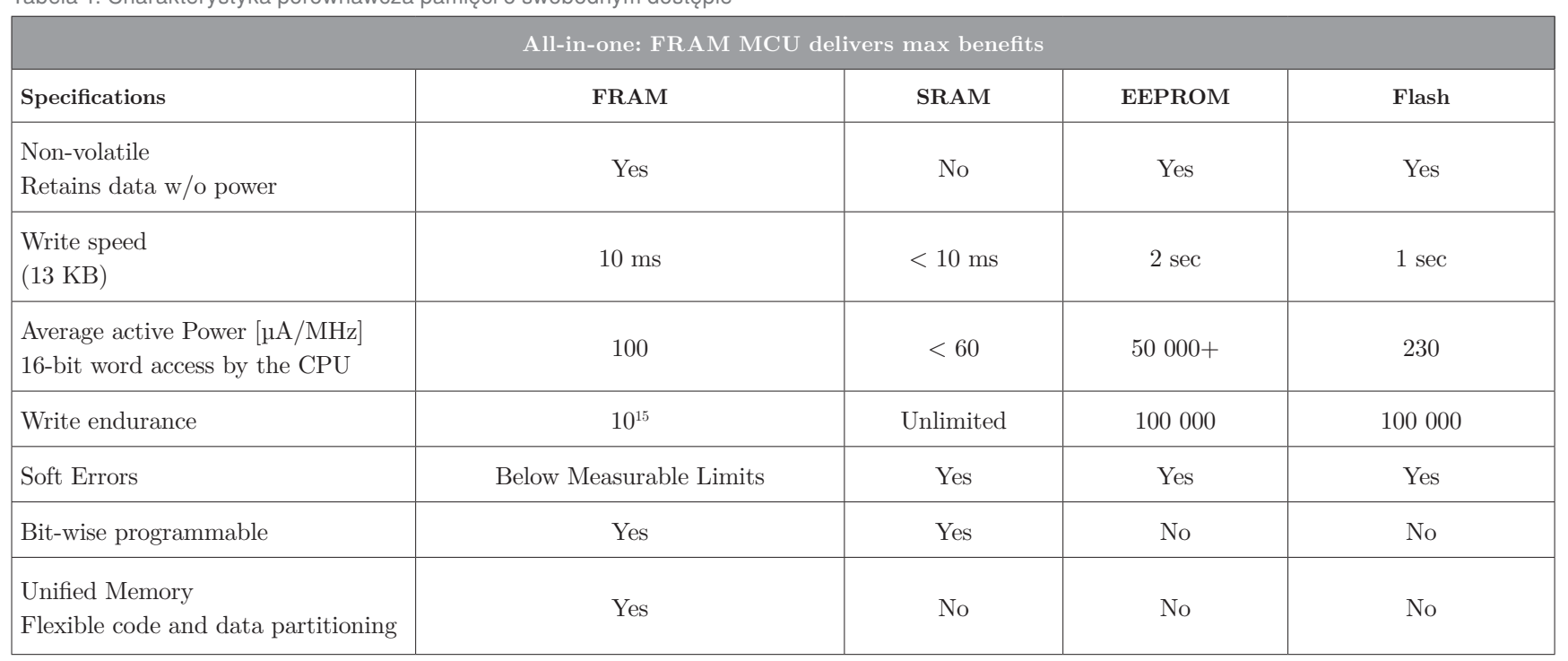


and at system crash followed by rebooting (the watchdog timer is responsible for this), not to carry out the repetitive measurements.

A wide range of both hardware and software development tools is available for system developers. To download and debug programs in MSP430 microcontroller only one flash emulator (FET), based on the MSP430 flash IC is required. USB and parallel ports are available to the user that allows conducting debugging at full speed, and modifying the contents of registers in real time. The embedded emulator (EEM) improves the debugging process. It allows up to 8 hardware breakpoints. It also includes a cycle counter, a clock rate control and a trace buffer. The software development tools inc- lude Code Composer Studio (with unlimited possibilities and a huge library of ready to use solutions), IDE Energia integrated development environment for Arduino compatible developments or MSPWare-Advanced system (Fig. 3). To improve the energy efficiency there are separate optimizers such as EnergyTrace software.

The mobile measurement system for monitoring the "smart clothes" parameters was developed $[4,5]$, making use of all the advantages of TI MSP430 microcontrollers.

The measurement system consists of deformation sensors 1-4, pressure sensors 5-8 and two combined temperature-humidity sensors 9, 10 (Fig. 4). Due to the fact that sensors 1-8 are the resistive- and strain gauge ones, for their approval the
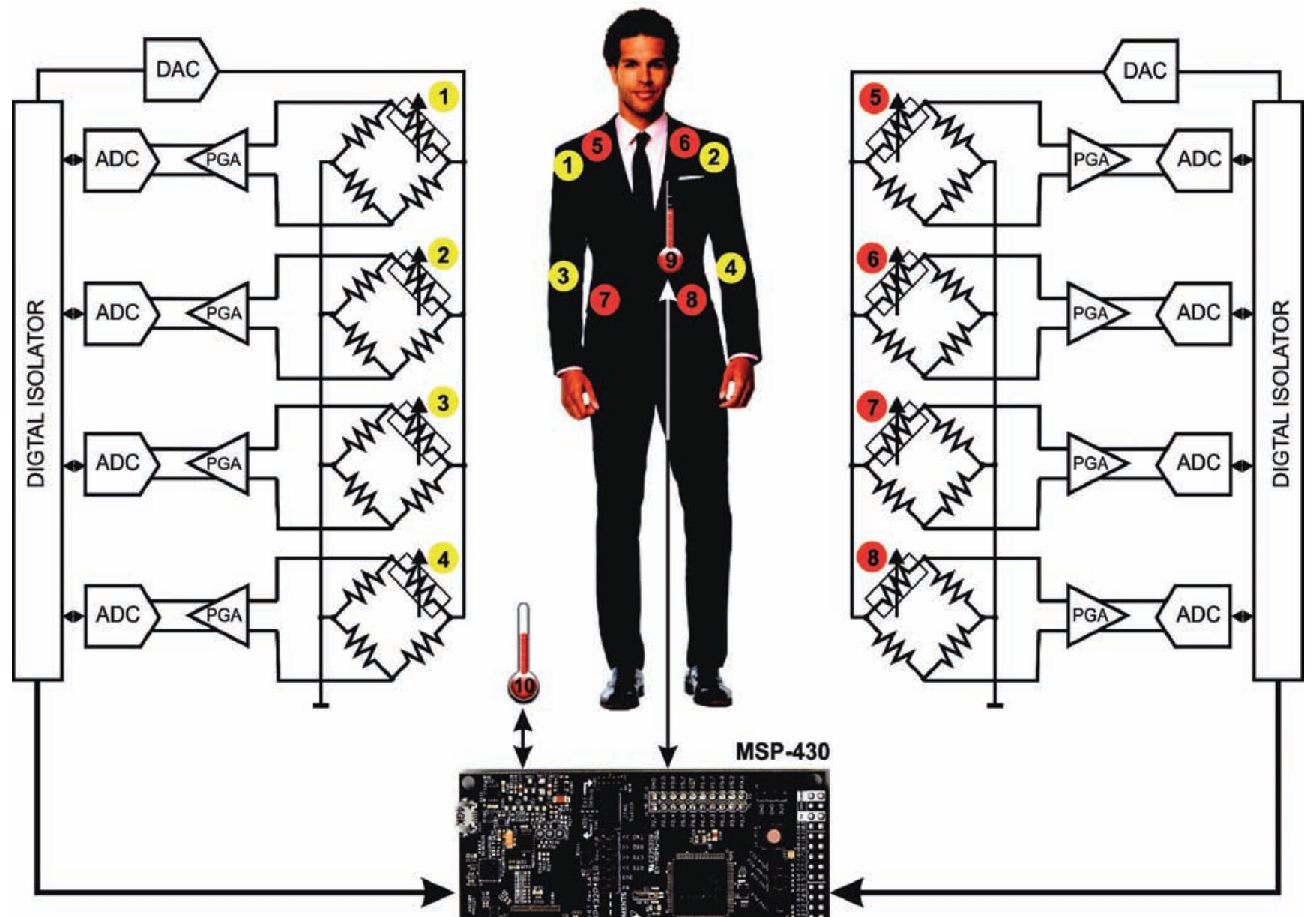

MSP-430

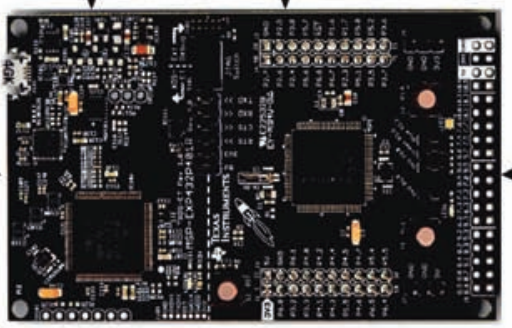

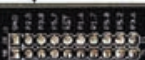

4

USB

Fig. 4. Monitoring "Man-Clothes" System parameters

Rys. 4. System monitorujący parametry

"inteligentnej odzieży" 


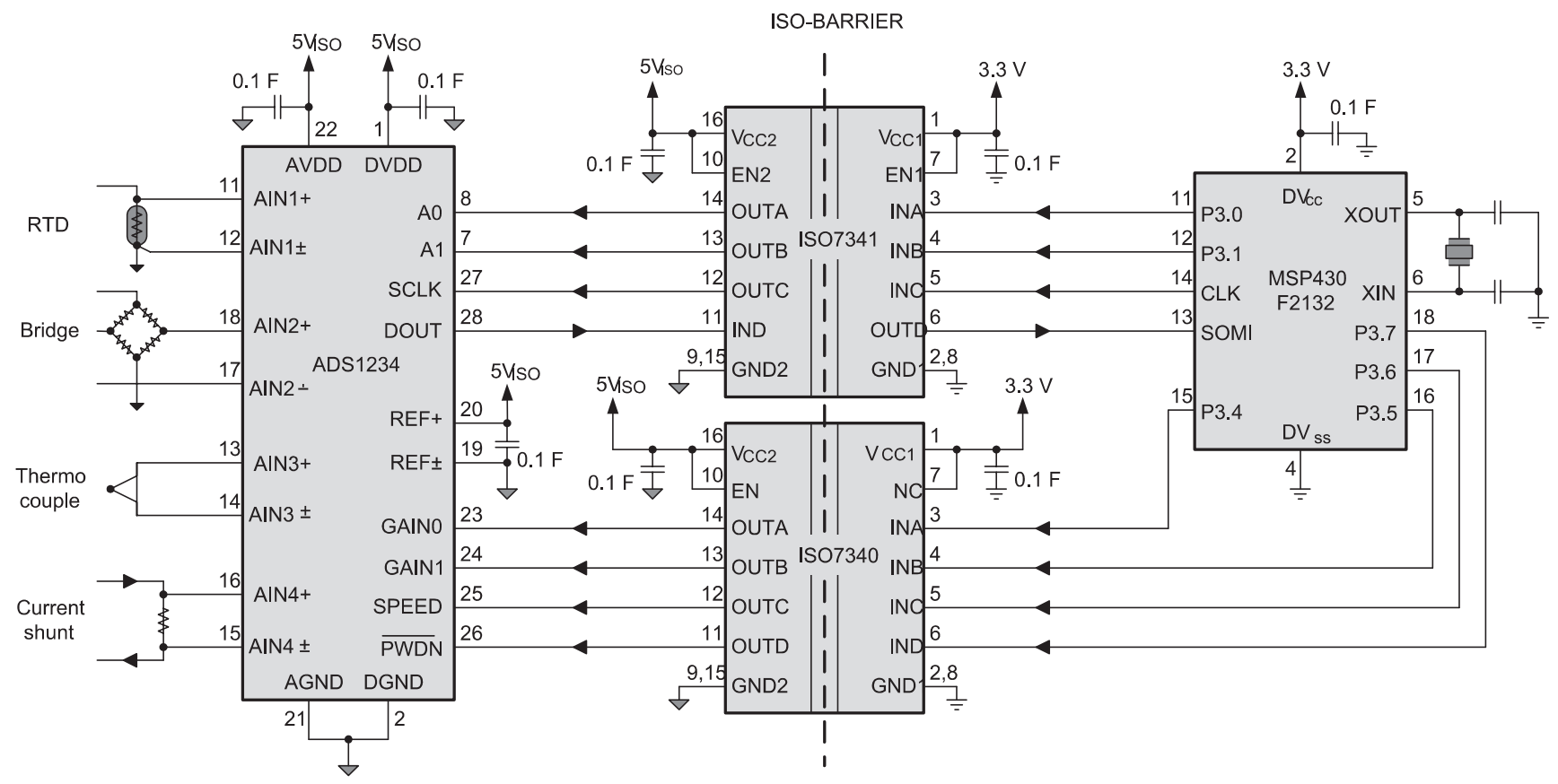

Fig. 5. Example of using the digital isolators

Rys. 5. Przykład użycia cyfrowych izolatorów

bridge switching circuit is used. The sensors are divided into two groups and powered by the digital-to-analog converters (DAC). This allows adjusting their sensitivity within a very wide range.

Each sensor signal is fed to a programmable gain amplifier (PGA), and further to the input of the analog-to-digital converter (ADC). The digital code that is responsible for strain and pressure through digital insulators (TI ISO7341 and ISO7340) is supplied to the input of TI MSP430FR5969 microcontroller, and after pre-processing through USB interface to the host computer. The use of digital isolators (Fig. 5.) protects a man (on whom the sensors are fixed) from the accidental voltage contact. The level of protection is more than $5000 \mathrm{~V}$. In addition, the galvanic isolation provides a significant reduction in noise from the digital part of the measurement system. The reading speed of measurement results changes with the use of the control program and can be within the range of 1-100 measurements per second for one channel.

Two combined temperature-humidity sensors (TI HDC1008), one of which is under the clothes, and the other outside, allow measuring the microclimatic conditions under the object of study, and controlling the air microcirculation.

If necessary, an unlimited increase in the number of measuring channels is possible using additional sensors (for example heart rate, blood pressure and oxygen saturation, etc.) within the range of one microcontroller. A similar problem can be solved by connecting of several described measurement systems to one computer (the number of controllers that can be connected by USB-bus simultaneously is almost unlimited). In future, the USB interface will be replaced by a wireless Wi-Fi and/or Bluetooth connection channel. The local accumulation of measurement results within the microcontroller (or SD Card) will be additionally implemented, which will significantly improve the prospects of using the system in the field conditions.
Due to the fact, that power of TI MSP430 microcontrollers is more than enough for the measurement and processing of signals from the sensors, the realization of local WEB-server based on it is possible. This will allow monitoring of the system through the smartphone's web browser, tablet or smart watches. In addition, this solution will convert the "smart clothes" into the Internet of Things (IoT) device.

\section{References}

1. Molnar A.A., Kuritnik I.P., Gerasimov V.V., Karabekova D.Zh., Pezoelektrichestvo kak istochnik elektroenergii dlya portativnyih elektronnyih ustroystv $v$ sisteme «chelovekodezhda», Vestnik karagandinskogo universiteta, Seriya FIZIKA, N 4(80), 2015, 62-65, ISSN 0142-0843 (in russia).

2. Electronic resource: www.ti.com/lsds/ti/microcontrollers_16-bit_32-bit/msp/ultra-low_power/overview.page.

3. Davies J., MSP430 Microcontroller Basics, Newnes, 2008, ISBN 978-0750682763.

4. Barrett S.F., Pack D.J., Microcontroller Programming and Interfacing: Texas Instruments MSP 430 (Synthesis Lectures on Digital Circuits and Systems), Morgan \& Claypool Publishers, 2011, ISBN 978-1608457137.

5. Jiménez M., Palomera R., Couvertier I., Introduction to Embedded Systems: Using Microcontrollers and the MSP430, Springer, 2014, ISBN 978-1461431428, DOI: 10.1007/9781-4614-3143-5.

6. Luecke J., Analog and Digital Circuits for Electronic Control System Applications: Using the TI MSP430 Microcontroller, Newnes, 2004, ISBN 978-0750678100.

7. Kurytnik I.P., Mikulski M., Karpiński W., Bezprzewodowa sieć sensorów, „Pomiary Automatyka Kontrola”, Vol. 56, Nr 6, 2010, 548-551. 


\section{Monitorowanie systemu „człowiek-odzież” na bazie nowoczesnych mikrokontrolerów}

Streszczenie: W artykule przedstawiono wyniki badań eksperymentalnych mobilnych urządzeń elektronicznych (wearable) dla monitoringu podstawowych parametrów system „człowiek-odzież” w oparciu o mikrokontroler TI MSP430.

Słowa kluczowe: elektronika noszona, system „człowiek-odzież”

\section{Alexander Molnar, PhD}

Born in 1965 in Uzhgorod, Ukraine. In 1989 he graduated from Uzhgorod State University (Department of Semiconductor Physics, specialty „Physicist Engineer"). Defended his Ph.D. thesis on "Low-frequency processes and the time dependent relaxation of the dielectric properties in the spontaneously polarized semiconductors" in 1994. Since 1994, a senior research fellow at the Institute of Physics and Chemistry of Solid State, UzhNU. Since 2009, assistant pro-

fessor of the department of semiconductor physics, UzhNU. Supervised courses: microprocessor technique, analog electronics, and functional electronics. Main areas of interest: the physics of ferroelectrics, automation of physical experiment.

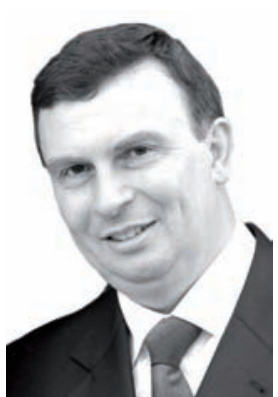

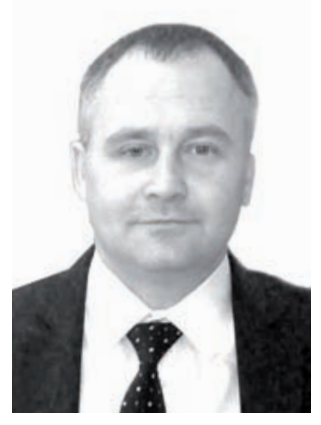

professor of Technological Faculty (Dep. of Light Technology) at Mukachevo State University. Main areas of interest: computer modeling in modern engineering CAD systems, technique of physical experiment, automation of measuring in light industry. 1994 Uzhgorod State University. Faculity of Physics. Specialization - „Physics and EngiElectronics Devices". 1994-1997 - post-graduate student at Uzhgorod State University Department of Solid State Electronics. 1998 - defended the thesis (CSS) on "Optica properties of thin films with high and low coordination number based on As-Ge-S and

\section{Prof. Igor Piotr Kurytnik, PhD, DSc}

\section{igor.kurytnik@pwsz-oswiecim.edu.pl}

He received the MSc in 1968 in the Faculty of Electronics and Automation of the Lviv Polytechnic. In 1973 received PhD, and in 1987 DSc degrees. From 2000 he worked at the Faculty of Mechanical Engineering and Computer Sciences of the University of Bielsko-Biała. We was the Head of Department of Electrical Engineering and Automation. Since 2015, he has been employed at the Department of Engineering Processes and Quality at State School of Higher Education in Oświęcim.

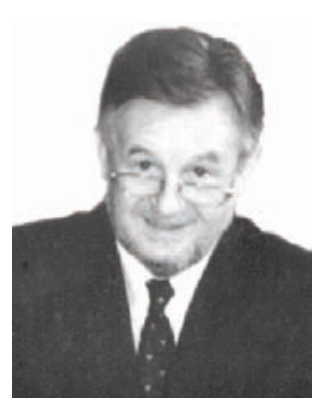

